\title{
Pendampingan Literasi Finansial Rumah Tangga Masyarakat Dusun Kawan Kabupaten Bengkayang
}

\author{
William Wendy Ary, Helena Anggraeni Tjondro Sugianto, Aloysius Hari Kristianto \\ Institut Shanti Bhuana \\ Email william.wendy@shantibhuana.ac.id
}

\begin{abstract}
ABSTRAK
Indonesia merupakan negara yang masuk sebagai anggota negara G-20 dan tentu saja memiliki tingkat perekonomian yang tinggi secara global. Salah satu sektor yang mendorong perekonomian Indonesia berasal dari sektor keuangan. Walaupun sektor keuangan merupakan salah satu kontributor terbesar, namun masih banyak warga negaranya yang belum terliterasi dengan baik pengetahuan keuangan terutama di Kabupaten Bengkayang dan tentu saja hal ini mendorong tim pengabdian masyarakat Institut Shanti Bhuana tergerak untuk melakukan kegiatan pengabdian kepada masyarakat Dusun kawan di Kabupaten Bengkayang. Kegiatan ini menggunakan tiga metode yaitu ceramah, tutorial dan praktik. Kegiatan pengabdian ini mendapatkan respon dan hasil yang cukup membahagiakan. Berdasarkan hasil survey kepuasan yang telah dilakukan kepada 33 peserta pendampingan, maka dapat disimpulkan bahwa kegiatan pengabdian masyakarakat ini telah meningkatkan pengetahuan literasi keuangan yang cukup signifikan kepada peserta. Implikasi dari kegiatan pendampingan ini sudah cukup meningkatkan kesadaran para peserta pentingnya berinvestasi, menabung, menentukan skala prioritas, serta mengantisipasi risiko keuangan

Kata kunci: Literasi Keuangan, Manajemen Keuangan Keluarga, Kabupaten Bengkayang, Pengabdian Masyarakat
\end{abstract}

\begin{abstract}
Indonesia is a country that has been categorized as one of G-20 countries and also indeed has a high level of economy globally. Financial Industry is one of the sectors that contributes Indonesian economy. However, even though the financial sector is one of the biggest contributors, there are still many Indonesia's citizens who are not with financially iterated, especially in Bengkayang Regency and this problem has motivated the community service team of the Shanti Bhuana Institute to carry out community service activities in Kawan Hamlet in Bengkayang Regency. This activity uses three methods, namely lectures, tutorials and practices. This community service received satisfying results from the participants. Based on the results of the satisfaction survey conducted on 33 mentoring participants, it can be concluded that this community service activity has significantly increased knowledge of financial literacy for the participants. The implications of this mentoring activity are sufficient to raise awareness of participants on the importance of investing, saving, determining priority scales, and anticipating financial risks.
\end{abstract}

Keywords: Financial Literacy, Family-based Financial Management, Bengkayang Regency, Community Service

\section{PENDAHULUAN}

Indonesia merupakan negara yang masuk kedalam negara G20 dengan tingkat Produk Domestik Bruto (PDB) sebesar USD 1,258,286,717,125 pada tahun 2019 (World Bank, 2020) dan angka PDB ini juga menunjukkan bahwa Indonesia menempatkan Indonesia sebagai salah satu dari enam belas negeri yang memiliki kinerja perekonomian yang baik secara global. Angka PDB yang tinggi ini juga diiringi dengan meningkatnya angka literasi keuangan masyarakat di Indonesia dan hal ini dapat ditunjukkan dari naiknya indeks literasi keuangan yang sebelumnya sebesar $29,7 \%$ pada tahun 2016 menjadi 38,03\% pada tahun 2019 (Otoritas Jasa Kuangan, 2019). Kenaikan indeks literasi keuangan merupakan informasi yang sangat membanggakan dan menunjukkan keberhasilan Pemerintah Indonesia dalam 
menaikkan kualitas sumberdaya manusianya melalui program-program yang sudah diimplementasikan selama empat tahun terakhir ini.

Namun, kenaikan indeks literasi keuangan ini tidak selalu dapat mencerminkan kondisi yang riil di beberapa wilayah yang ada di Indonesia, salah satunya di Kabupaten Bengkayang. Kabupaten Bengkayang merupakan salah satu kabupaten yang berada di Kalimantan Barat dan masih terkategori sebagai daerah afirmasi 3T (Terdepan, Terluar, dan Tertinggal). Oleh karena itu, tidaklah mengherankan apabila Kabupaten Bengkayang memiliki angka indeks pembangunan manusia (IPM) rendah yang hanya sebesar 66,85 dan angka IPM ini sangat jauh terlampau rendah apabila dibandingkan dengan IPM secara nasional sebesar 71,92 pada tahun 2019 (BPS, 2019). Maratade et al. (2016) dan Ezkirianto \& Alexandi (2018) menyebutkan bahwa ada hubungan kausalitas positif antara IPM dengan Pertumbuhan Ekonomi dan dalam penelitian mereka ini juga memiliki implikasi bahwa untuk menaikkan tingkat perekonomian sebuah daerah maka harus meningkatkan kualitas sumberdaya manusianya terlebih dahulu. Tingkat pengetahuan juga menjadi salah satu tolok ukur yang mendorong tingkat pembangunan manusia di sebuah wilayah (United Nations Development Programme, 2020).

Dusun Kawan merupakan salah satu dusun yang berada di Desa Sukamaju Kabupaten Bengkayang. Mayoritas penduduk dusun kawan berprofesi sebagai petani dan hasil komoditas utama yang menjadi mata pencaharian adalah Padi dan Jagung. Berdasarkan hasil diskusi bersama beberapa masyarakat sekitar, mayoritas masyarakat yang hidup di dusun in berprofesi sebagai petani dan masing-masing memiliki lahan garapan seluas setengah hektar atau sekitar $5.000 \mathrm{~m} 2$.

Namun, dengan lahan yang seluas tersebut masyarakat dusun kawan masih belum dapat memaksimalkan lahan yang tersedia tersebut secara maksimal. Beberapa alasan yang dikemukan oleh masyarakat adalah kurangnya pengetahuan dalam pengelolaan lahan yang benar, kurangnya pengetahuan dalam mengelola pendapatan yang diperoleh dari penjualan komoditas padi maupun jagung, serta kurangnya pendampingan yang diberikan oleh pemerintah daerah kepada mereka. Selain bertani, masyarakat dusun kawan desa sukamaju kecamatan sungai betung juga berprofesi sebagai peternak dan hewan yang diternakkan adalah mayoritas ayam dan babi kampung. Namun, seperti permasalahan komoditas pertanian, masyarakat dusun kawan juga merasa belum memiliki kemampuan untuk memelihara dan merawat hewan ternak ini.

Selain, permasalahan dalam pengelolaan potensi pertanian, permasalahan lainnya yang dihadapi oleh masyarakat dusun kawan adalah belum adanya edukasi yang diberikan kepada masyarakat untuk dapat mengelola aset keuangan keluarga yang benar terutama dalam hal perencanaan dan penganggaran keuangan yang ideal dalam memelihara hewan hewan ternak tersebut seperti alokasi ideal dalam biaya pakan, biaya pembuatan kendang serta biaya-biaya pemeliharaan hewan lainnya dengan harapan omset yang diperoleh dari pemeliharaan sampai penjualan hewan ternak tersebut bisa menghasilkan keuntungan yang maksimal.

Permasalahan-permasalahan yang dihadapi oleh para masyarakat dusun kawan ini kemudian ditindaklanjuti dalam kegiatan pengabdian masyarakat yang dilakukan oleh Program Studi Manajemen Institut Shanti Bhuana. Dalam kegiatan pengabdian ini, peserta didampingi dengan intensif selama sepuluh bulan dari bulan Maret sampai November 2020.

\section{BAHAN DAN METODE}

Pelatihan pengelolaan keuangan keluarga bukan hal yang asing lagi bagi banyak daerah yang sudah memberikan pelatihan maupun pendampingan serupa dan kegiatan seperti ini sudah banyak memberikan manfaat yang signifikan bagi peserta yang terlibat. Pelatihan ini bertujuan agar masyarakat dapat mengelola keuangan keluarga dengan baik dan mampu mengelola pendapatan untuk kesejahteraan keluarga. Yang dilakukan dari pelatihan ini adalah memberikan pelatihan dasar laporan keuangan dasar seperti laporan 
arus kas, catatan atas laporan keuangan serta konsep dasar investasi (pendanaan, investasi dan modal kerja).

Target peserta yang mengikuti kegiatan pendampingan ini adalah pasangan suami istri beserta anak muda sebanyak 33 orang dan dilaksanakan di Gereja Stasi Santa Elisabeth Dusun Kawan Kabupaten Bengkayang yang berjarak $\pm 15.6 \mathrm{~km}$ dari lokasi Institut Shanti Bhuana. Kegiatan Pelatihan dan Sosialisasi ini tidak hanya memberikan pengetahuan saja kepada masyarakat namun akan memberikan bekal materi berupa modul atau handbook yang sangat berguna bagi masyarakat supaya proses pembelajaran tetap berkesinambungan.

Pelaksanaan kegiatan Program Pengabdian pada Masyarakat ini dilakukan dengan menggunakan metode ceramah, tutorial, dan praktik. Metode ceramah dilakukan dengan memberikan wawasan mengenai literasi pengelolaan dan pengaturan keuangan keluarga sederhana. Metode tutorial dilakukan dengan memberikan peserta materi tentang bagaimana mengatur arus kas masuk dan keluar, mengalokasikan pendapatan yang diperoleh dari hasil penjualan hasil tani/ternak dalam bentuk savings dan konsumsi pribadi serta bagaimana menghitung kelayakan usaha secara sederhana. Materi ini disampaikan dalam bentuk tutorial disertai dengan latihan/studi kasus. Metode praktik dilakukan dengan memberikan kesempatan kepada peserta untuk mempraktikkan hasil yang sudah disampaikan yang berkaitan dengan pengelolaan dan pengaturan keuangan keluarga sederhana. Langkah ketiga diselenggarakan selama maksimal 1 jam. Selain ketiga metode tersebut, kegiatan pengabdian ini juga memberikan pendampingan keuangan keluarga melalui media daring Whatsapp untuk mendukung upaya pengabdian ditengah masa pandemi covid-19.

\section{HASIL}

Kegiatan pengabdian ini dihadiri oleh 33 orang peserta yang berasal dari kaum muda dan kaum dewasa. Kegiatan ini berhasil dilaksanakan selama dua kali dalam sepuluh bulan yaitu dari bulan Maret sampai November 2020. Selain itu, pengabdian masyarakat ini juga mendampingi dalam bentuk mentoring secara daring melalui aplikasi android Whatsapp (Lihat Gambar 1) dengan membuatnya dalam bentuk grup. Selama sepuluh bulan tersebut masyarakat diberikan materi menggunakan metode - metode yang telah diuraikan dalam bagian bahan dan metode.

Kegiatan pengabdian ini mendapatkan umpan balik yang positif dari masyarakat dusun kawan yang hadir secara aktif selama periode pengabdian. Sebanyak 23 peserta mengatakan paham terhadap keseluruhan materi di kisaran $76-100 \%, 8$ peserta mengatakan paham terhadap keseluruhan materi di kisaran $50-75 \%$, dan hanya 2 peserta yang mengatakan paham terhadap keseluruhan materi di kisaran dibawah $50 \%$ (Lihat Gambar 2). Sebanyak $54,5 \%$ peserta merasa cukup puas dengan kegiatan pengabdian yang telah dilaksanakan dan sisanya sebesar $45,5 \%$ merasa sangat puas terhadap pelaksanaan kegiatan pengabdian masyarakat (Lihat gambar 3). Secara keseluruhan kegiatan pengabdian masyarakat yang dilaksanakan mendapatkan respon yang sangat positif dari masyarakat yang aktif berpartisipasi dalam kegiatan pengabdian masyarakat.

\section{PEMBAHASAN}

Pada tahapan awal dalam kegiatan pengabdian masyarakat di dusun kawan ini, tim pengabdian yang terdiri dari tiga orang beserta dua orang mahasiswa melakukan audiensi kepada masyarakat dusun kawan di Gereja Santa Elisabeth Stasi Dusun Kawan. Kegiatan ini dilakukan untuk dapat mengidentifikasi kebutuhan-kebutuhan pendampingan yang dibutuhkan oleh masyarakat setempat. Salah satu kebutuhan pendampingan yang dibutuhkan oleh masyarakat salah satunya terkait dengan pengelolaan keuangan keluarga.

Selanjutnya, setelah berhasil mengidentifikasi kebutuhan masyarakat tim pengabdian langsung menyiapkan dan merencanakan materi edukasi beserta pendampingan yang akan 
diberikan kepada masyarakat. Setelah menyiapkan dan merencanakan, tim pengabdian langsung kembali berdiskusi bersama ketua kelompok masyarakat untuk mencari jadwal yang cocok untuk pelaksanaan kegiatan pengabdian masyarakat di dusun kawan. Setidaknya ada dua kali kegiatan pendampingan secara tatap muka (lihat gambar 4) dan sisanya pendampingan dilakukan dengan media daring seperti Whatsapp. Dari kegiatan pengabdian yang dilakukan para peserta tertarik dan semakin optimis untuk segera mengimplementasikan ide bisnis yang sudah mereka rencanakan sebelumnya karena sudah terbekali dengan pendampingan dari segi pengelolaan keuangan. Untuk membekali peserta kegiatan, tim pengabdian juga memberikan modul yang dikonversikan kedalam bentuk modul pdf yang berjudul "Modul Pelatihan Keuangan" (lihat gambar 5). Modul ini diberikan supaya peserta kegiatan pengabdian tetap dapat mempelajari kembali materi pendampingan keuangan dan dapat diakses secara fleksibel.

\section{KESIMPULAN DAN SARAN}

Indonesia merupakan negara yang termasuk kedalam golongan negara G-20 dan ini tentu saja mengindikasikan bahwa perekonomian merupakan salah satu negara yang memiliki tingkat perekonomian yang tinggi secara global. Tentu saja hal ini tidak lepas dari kontribusi dari kualitas sumberdaya manusia yang ada karena ada hubungan yang positif antara tingkat perekonomian sebuah negara dan kualitas sumberdaya manusianya. Kabupaten Bengkayang merupakan salah satu Kabupaten yang memiliki tingkat IPM yang rendah dibandingkan dengan rata-rata secara nasional sehingga sangat membutuhkan perhatian dari berbagai pihak untuk meningkatkan kualitas SDM yang ada di Kabupaten Bengkayang.

Salah satu kelompok masyarakat di Kabupaten Bengkayang yang membutuhkan pendampingan dalam hal ini adalah masyarakat yang ada di Dusun Kawan Tim pengabdian masyarakat dari Institut Shanti Bhuana kemudian melakukan pendampingan dari aspek literasi dan pengelolaan keuangan keluarga dengan menggunakan tiga metode yaitu ceramah, tutorial dan praktik. Kegiatan pengabdian ini mendapatkan respon dan hasil yang cukup membahagiakan dimana $54,5 \%$ peserta merasa cukup puas dengan kegiatan pengabdian yang telah dilaksanakan dan sisanya sebesar $45,5 \%$ merasa sangat puas terhadap pelaksanaan kegiatan pengabdian masyarakat. Sebanyak 23 peserta mengatakan paham terhadap keseluruhan materi di kisaran $76-100 \%, 8$ peserta mengatakan paham terhadap keseluruhan materi di kisaran $50-75 \%$, dan hanya 2 peserta yang mengatakan paham terhadap keseluruhan materi di kisaran dibawah $50 \%$. Berdasarkan hasil survey kepuasan yang telah dilakukan kepada 33 peserta pendampingan, maka dapat disimpulkan bahwa kegiatan pengabdian masyakarakat ini telah meningkatkan pengetahuan literasi keuangan yang cukup signifikan kepada peserta. Implikasi dari kegiatan pendampingan ini sudah cukup meningkatkan kesadaran kepada para peserta mengenai pentingnya berinvestasi, menabung, menentukan skala prioritas, serta mengantisipasi risiko keuangan.

\section{UCAPAN TERIMA KASIH}

Tim pengabdian masyarakat Institut Shanti Bhuana mengucapkan banyak terima kasih kepada Yayasan Santo Yohanes Salib yang sudah mendukung kegiatan pengabdian masyarakat di Dusun Kawan Kabupaten Bengkayang baik dari segi dukungan moral dan alokasi dana pengabdian masyarakat. Tim pengabdian juga mengucapkan banyak terima kasih kepada Bapak Markas selaku Kepala Desa Sukamaju, Bapak Anton selaku Koordinator Umat Gereja Stasi Santa Elisabeth beserta seluruh masyarakat Dusun Kawan yang tidak dapat disebutkan satu per satu. 


\section{DAFTAR PUSTAKA}

BPS. (2019). Data Indeks Pembangunan Manusia Kabupaten Bengkayang Tahun 2010-2019. Retrieved December 3, 2020, from Data series Badan Pusat Statistik website: https://bengkayangkab.bps.go.id/indicator/26/48/1/ipm.html

Ezkirianto, R., \& Alexandi, M. F. (2018). Analisis Keterkaitan Antara Indeks Pembangunan Manusia Dan Pdrb Per Kapita Di Indonesia. Jurnal Ekonomi Dan Kebijakan Pembangunan, 2(1), 14-29. https://doi.org/10.29244/jekp.2.1.14-29

Maratade, S. Y., Rotinsulu, D. C., Niode, A. O., Pembangunan, J. E., Ekonomi, F., \& Bisnis, D. (2016). Analisis Pertumbuhan Ekonomi Dan Indeks Pembangunan Manusia Di Provinsi Sulawesi Utara ( Studi Pada Tahun 2002-2013 ). Jurnal Berkala IImiah Efisiensi, 16(01), 328-338.

Otoritas Jasa Keuangan. (2019). Siaran Pers Survei OJK 2019 Indeks Literasi Dan Inklusi Keuangan Meningkat. Retrieved December 3, 2020, from Deputi Komisioner Hubungan Masyarakat dan Manajemen Strategis website: Deputi Komisioner Hubungan Masyarakat dan Manajemen Strategis

United Nations Development Programme. (2020). Human Development Index (HDI). Retrieved November 30, 2020, from Human Development Report Office Team website: http://hdr.undp.org/en/content/human-development-index-hdi

World Bank. (2020). Data GDP (PDB) Seluruh Negara. Retrieved from https://data.worldbank.org/indicator/NY.GDP.MKTP.CD 


\section{LAMPIRAN}

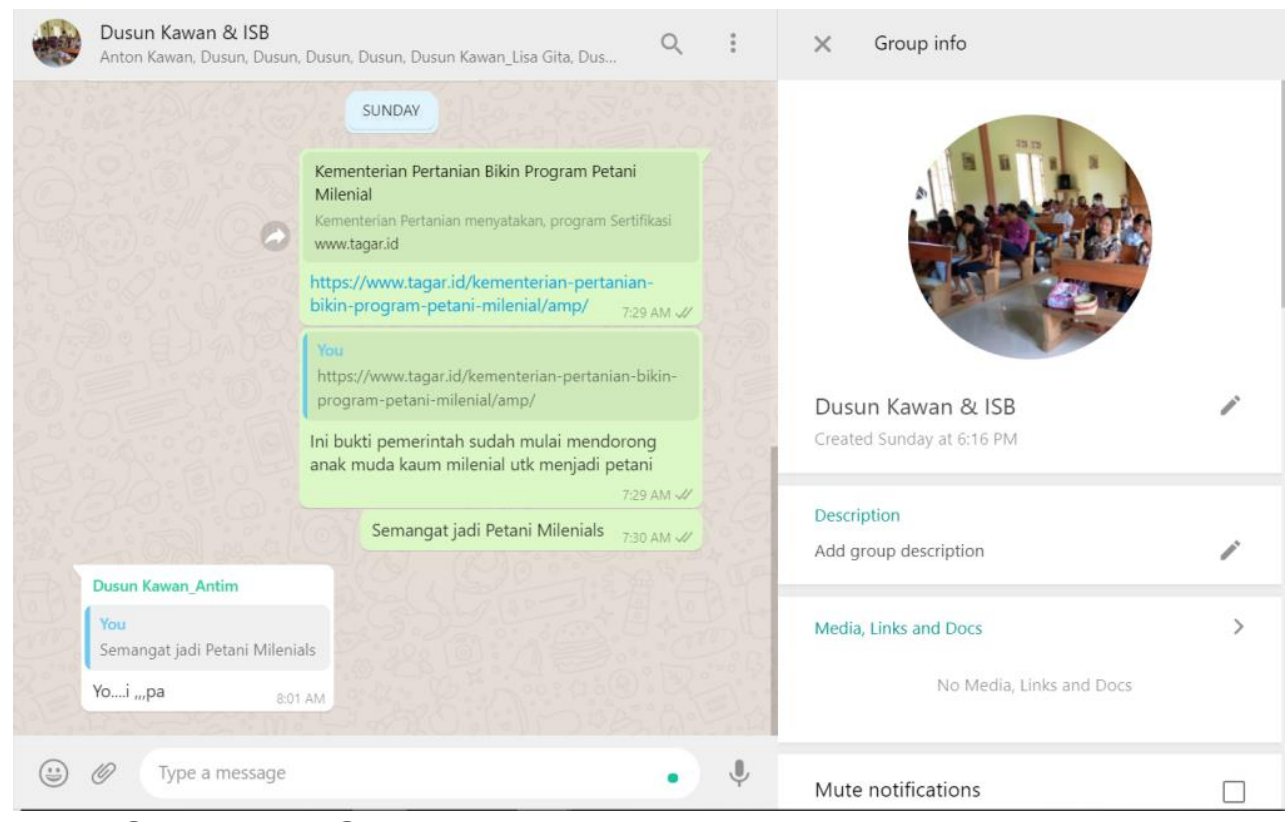

Gambar 1. Grup Whatsapp Pendampingan Masyarakat

Tingkat Pemahaman terhadap Keseluruhan Materi

33 responses

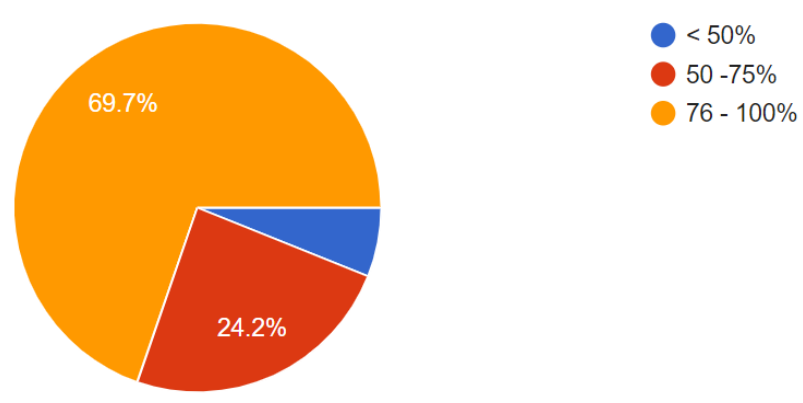

Gambar 2. Grafik Tingkat Pemahaman terhadap Keseluruhan Materi 
Kepuasan Anda terhadap Keseluruhan Kegiatan

33 responses
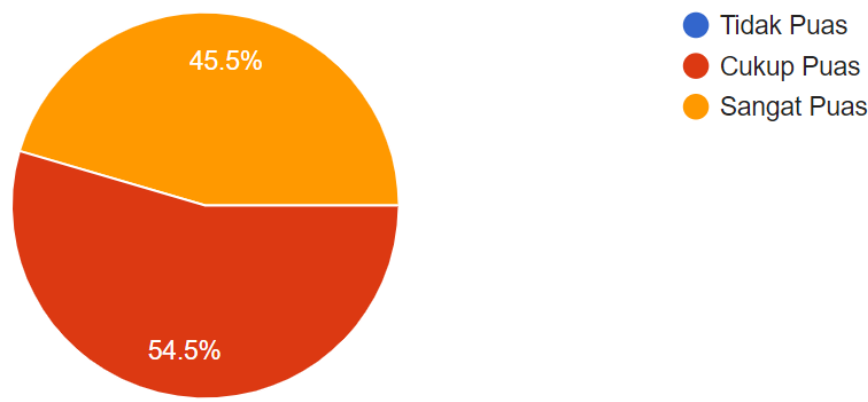

Gambar 3. Grafik Kepuasan terhadap Keseluruhan Kegiatan

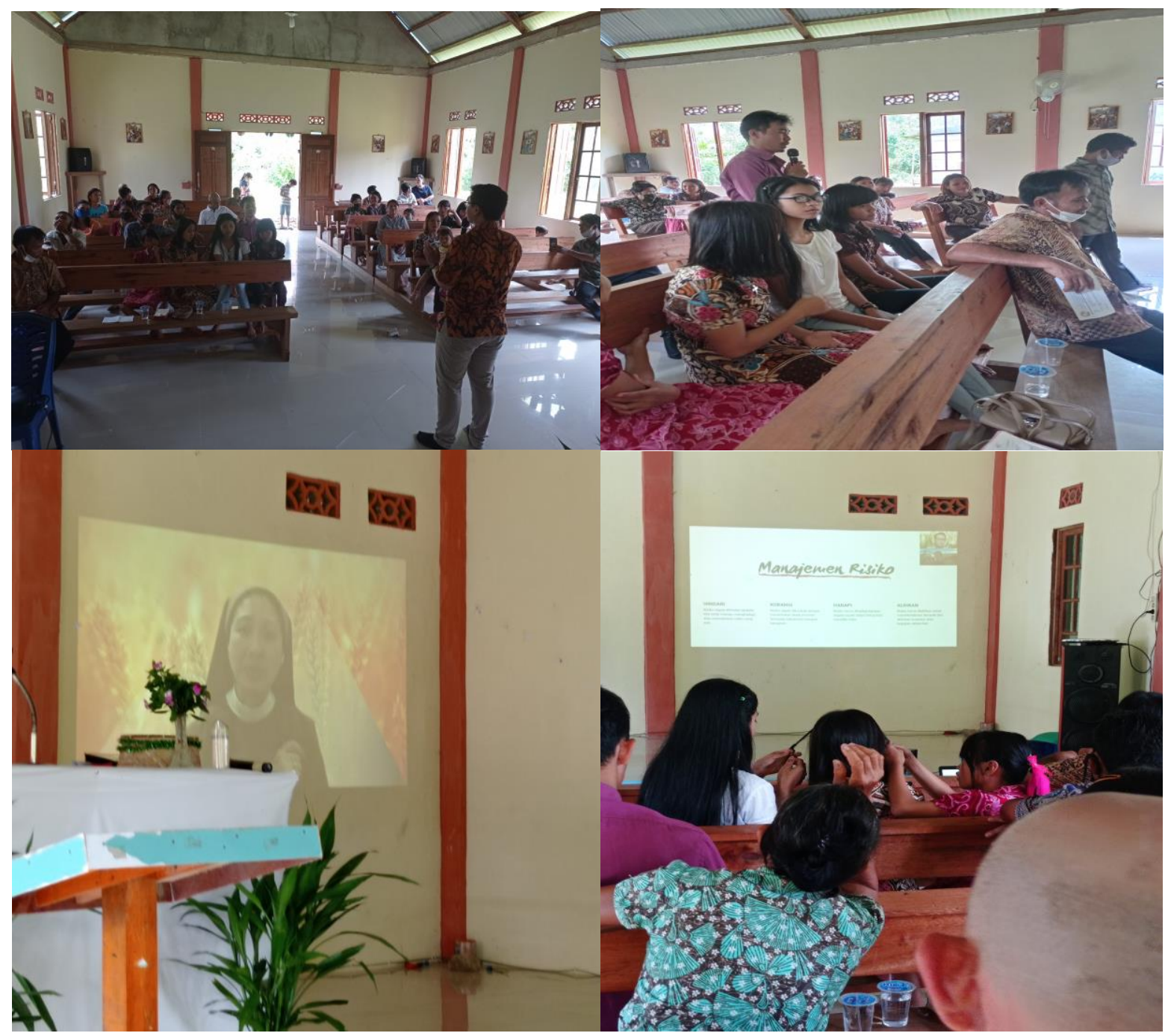

Gambar 4. Kegiatan Pendampingan Tatap Muka 


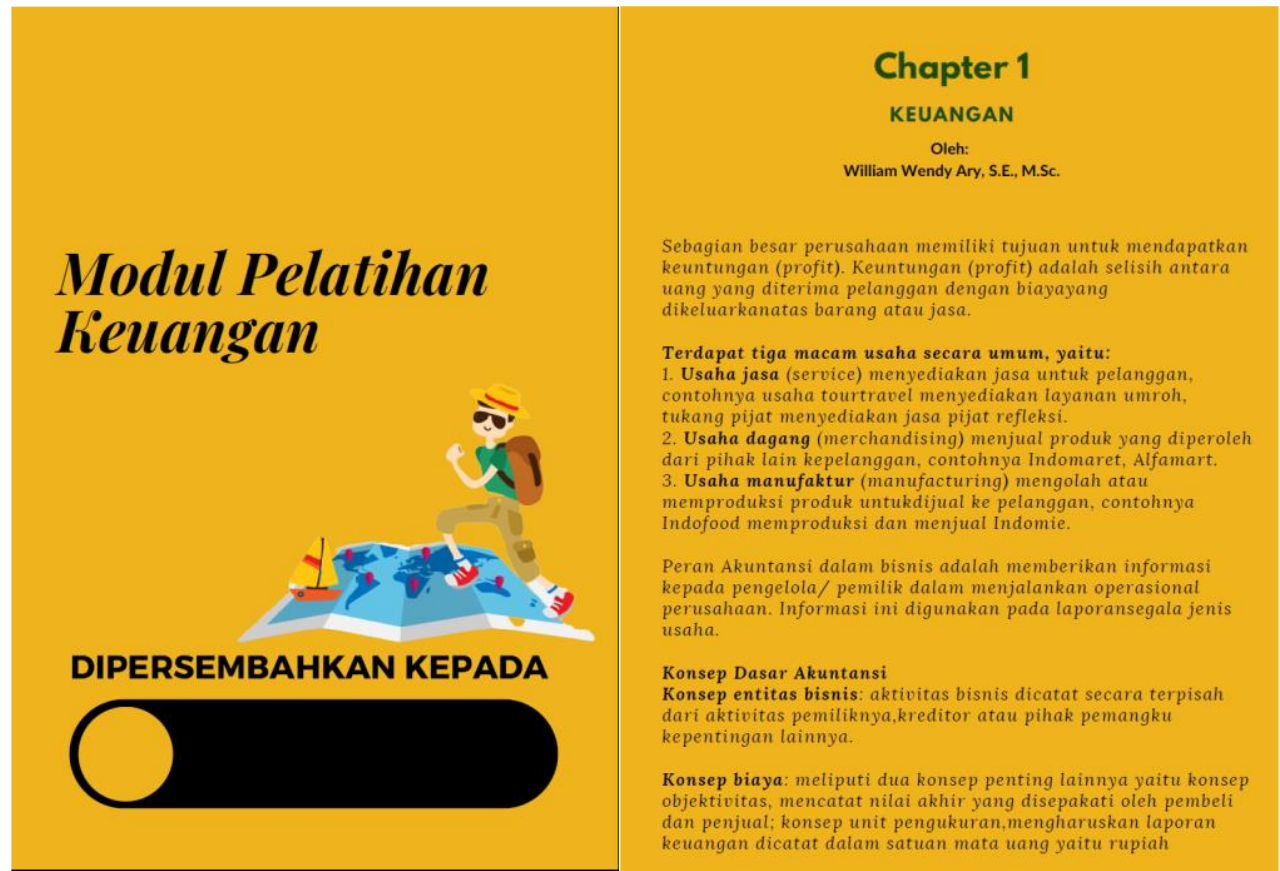

Gambar 5. Modul Pendampingan Literasi Keuangan 